\title{
Metal Uptake and Accumulation by Mangrove Plant Species in Pattani Bay, Thailand
}

\author{
Weeradej Meeinkuirt ${ }^{1}$, Pungtip Kaewtubtim², Sumalee Seepom ${ }^{2}$, John Pichtel $^{3}$ \\ ${ }^{1}$ Mahidol University, Nakhonsawan Campus \\ Nakhonsawan 60130, Thailand \\ weeradej.mee@mahidol.ac.th \\ ${ }^{2}$ Department of Science, Faculty of Science and Technology, Prince of Songkla University Pattani Campus \\ Pattani 94000, Thailand \\ ${ }^{3}$ Ball State University, Natural Resources and Environmental Management \\ Muncie, IN 47306 USA
}

\section{Extended Abstract}

The mangrove ecosystem of Pattani Bay, Thailand, has received inputs of heavy metals from both industrial and domestic sources for several decades. Phytomanagement is a beneficial strategy for soil and sediment remediation over extensive areas. A total of 18 major plant species within 14 families were identified within the Pattani mangrove forest. They were categorized based on plant habits as follows; groundcover (Ipomoea pes-caprae, Phyla nodiflora, Sesuvium portulacastrum, Wedelia biflora); climbing plants (Derris trifoliata, Passiflora foetida); grass plants (Dichanthium caricosum, Phragmites karka), shrub (Acanthus ebracteatus, Avicennia alba, A. marina, Pluchea indica); trees (Thespesia populnea, Rhizophora mucronata); aquatic plants (Cyperus involucratus, Eleocharis dulcis, Typha angustifolia), and pteridophyte plants (Acrostichum aureum). Soil material and plant tissue from selected species were evaluated for heavy metal concentrations. Plants accumulated a range of heavy metals, mostly, in low quantities, as a function of species. Highest concentrations in plant tissue were 41.5, 29.8, 60.2, 322.5, 107.1, 0.5 and $75.7 \mathrm{mg} \mathrm{kg}^{-1}$ for copper $(\mathrm{Cu})$, zinc $(\mathrm{Zn})$, nickel $(\mathrm{Ni})$, manganese $(\mathrm{Mn})$, chromium $(\mathrm{Cr})$, cadmium $(\mathrm{Cd})$ and lead $(\mathrm{Pb})$, respectively. Considering the significant biomass production of several species, however, several may hold promise for phytoremediation of soil metals. The mangrove species in this study are considered metal excluders, since they accumulate metals primarily in roots with translocation factor values $<1$ and bioconcentration factors $>1$. Examples include A. marina for $\mathrm{Zn}, \mathrm{Cr}$, and $\mathrm{Pb} ; A$. alba for $\mathrm{Mn}$; and R. mucronata for $\mathrm{Cu}$ and $\mathrm{Zn}$. Some species accumulated metals in shoots; however, they cannot be classified as hyperaccumulators since metal concentrations were not sufficiently high to fit the criteria for plants in a phytoextraction strategy, even those with $\mathrm{TF}>1$ and $\mathrm{BCF}>1$ such as $T$. populnea for $\mathrm{Ni}$ and $C$. involucratus for $\mathrm{Cr}$.

Many plant species in mangrove ecosystems are edible and/or used as herbal medicines; the relatively low concentrations of heavy metals in the studied plants ensure that consumption by humans is safe. For selected species the woody components offer economic benefits such as biomass energy and construction uses. Monitoring of metallic contaminants in mangrove ecosystems is necessary to assess long-term trends of potential environmental and public health hazards. Phytoremediation may be used to assist in determining potential accumulation of metals in biota and environmental samples. This low-cost, solar-driven technology may serve to control and/or remove contaminants via plant uptake and accumulation with no adverse environmental effects.

Keywords: Metal, Accumulation, Mangrove, Plant Species, Pattani Bay 